\title{
Do This in Remembrance of Me Online? Irenic and Elenctic Normativity in Liturgical Studies
}

\author{
Marcel Barnard, Mirella Klomp and Maarten Wisse
}

\section{Abstract}

The authors of this article, two liturgical scholars and a scholar in dogmatics, engaged in a public discussion of whether or not a Holy Communion should be celebrated online. Speaking about the case afterwards, they found that both the discourse of liturgical studies and of dogmatics introduced comparable normative elements. Barnard and Klomp in liturgical studies speak with Ronald Grimes of 'ritual criticism' and with Roy Rappaport of 'The True Words' as benchmarks that are established by religions in the infinite field of meanings of the rite. Wisse speaks on the basis of the originally Lutheran distinction of Law and Gospel of therapeutic or irenic and elenctic normativity. The authors advocate this distinction as an instrument that opens the way for a discussion about the mystery of life and of the sacraments.

\section{Keywords}

Irenic and elenctic normativity, theology, liturgical studies, digital Holy Communion

\section{Introduction: the case in which the authors became involved}

With the sudden transition from physical to online forms of worship at the beginning of the COVID-19 pandemic, many churches were confronted with a number of ritual infelicities that had a large impact. One infelicity sparked a debate in March 2020, fueled in particular by the approaching Easter Triduum: the theological possibility or impossibility of a digital celebration of the sacraments, particularly the Holy Communion.

In the Netherlands, the debate surfaced in the week prior to Holy Week in two publications that both took a normative stance, though in seemingly opposite directions. The synodal board of the Protestant Church in the Netherlands (PCN) published guidelines on its website stating that the Holy Communion could not be missed, particularly during the Easter Triduum. "It is good," it read, "to prepare bread and wine at home prior to the online service, and, if this makes communion with the Lord more 
real to you, to actually consume it" [when in the rite the moment of the communion arrived]. ${ }^{1}$ Only a few days later, national newspaper Trouw published an opinion piece by Marcel Barnard and Mirella Klomp (both members of the PCN and liturgical scholars), who recommended that sacramental celebrations be postponed until the congregation could meet again physically in the church building and that there should, therefore, be no digital forms of sacramental communion. ${ }^{2}$

As with almost every aspect of life during the pandemic, the debate that followed mainly took place online (primarily on Twitter and Facebook, though also via email). Some applauded the stance of the synodal board for its pastoral efforts to support people in difficult times; others criticized it as 'un-ecumenical exit' taken without much theological consideration. Barnard and Klomp too received praise, but were also criticized for their 'cold-hearted' advice to refrain from digital forms of celebration at a time when people should be longing for the sacrament more than ever.

Initially - that is, earlier in the pandemic - the PCN had given different advice, recommending not to celebrate the Lord's Supper during online services. The third author of this article, Maarten Wisse, a scholar in dogmatics, commented on this advice in a nuanced way on Facebook, after which he was contacted by church officials for his opinion. Refraining from offering a recommendation, he chose an irenic approach to the normative role of theology. The document he wrote upon the PCN's request sketched possible approaches to the question of how one would deal with the Lord's Supper in online services. Wisse presented the approach of Barnard and Klomp as a viable solution to the problem, but also stressed that this could mean that faith communities would not celebrate the Lord's Supper for a very long time. He said that although this would be a sign of high respect for the sacrament, it would at the same time reinforce a long tradition of neglect of the sacrament in Protestant congregations in the Netherlands.

1) “Het is goed om ook thuis van te voren brood en wijn als zichtbare tekens van het lichaam en bloed van Christus klaar te zetten. $U$ kunt brood en wijn ook daadwerkelijk nuttigen, wanneer de verbondenheid met Christus daardoor voor u reëler wordt." "Moderamen over vieren Avondmaal in coronatijd," accessed November 20, 2020, https://www.protestantsekerk.nl/nieuws/moderamen-over-vieren-avondmaal-in-coronatijd/.

2) Marcel Barnard and Mirella Klomp, "Het avondmaal overslaan uit lijfsbehoud, dat is pas solidariteit" (Skipping the Holy Communion to preserve life, that's what solidarity means), Trouw, March 27, 2020. The online newspaper published the same piece under a different, more provocative, heading: "Thuis klaarzitten met brood en wijn voor de digitale avondmaalviering? Daarmee slaat u de plank mis" (Sitting by the digital celebration of Holy Communion with bread and wine at home? You're missing the point) and shared it on social media. Barnard and Klomp advised against either a (streamed or recorded) digital distribution of an analogous celebration in the church building or a 'mixed form' where people prepare and eat bread and drink wine at home at the moment of the communion. 


\section{The question for normativity that emerges from the} case

As the three of us teach at the same university, we discussed the case in which we had become involved and about which we seemed to have similar questions, all of which circle around the role of normativity in theology. What standards do we wish to adhere to? In this case, who sets the standards when it comes to liturgy and, especially, to the sacraments in celebrations performed (partly) online? Does theological expertise play a role in setting these standards, and who decides what role that should or could be? What, in a culture where authority no longer automatically lies with institutions (the church, the university), their leaders (the synodal board), or specialists (the academics), is our task as scholars in theology? In broader terms, what is the role of normative theology in liturgical studies? In this article, we have summarized these concerns in the central question: What do we expect from contemporary liturgical scholars and theologians with regard to normativity? Is their role merely descriptive and analytic, pointing out the consequences of positions, or can they also take and defend a particular, substantiated position? It is not superfluous to note here that we ask these questions from a Protestant perspective - that is, from the point of view of a denomination that traditionally leaves worship decisions largely to the local faith community and that has no central magisterium.

Because we have heard these questions addressed to ourselves during the debate, we will not keep ourselves out of this article. Nor is this the first time that we've thought about these questions. However, both the questions raised within the context of this debate and the cooperation between the three of us have sharpened our thinking: we all regularly face the question of whether and if so how we can or should make normative statements.

In the past we have all been accused in more or less friendly terms of positioning ourselves as the 'liturgical police' or the 'religious police', focusing on the enforcement of what is supposed to be theologically correct rather than on making a constructive contribution to a problem in a very specific context. At the same time, we have also been accused of being too relativistic and descriptive and of avoiding normative statements. What position can and should an academic theologian occupy here?

\section{Perspectives on normativity in theology, specifically in liturgical studies}

\section{Liturgical Studies: Ritual Criticism and 'True Words'}

On the one hand, through our (Barnard and Klomp) work in liturgical studies we partly identify both with the liturgical ritual that we are researching and with the liturgical ritual actors - any group in the public sphere, an ecclesiastical congregation, or church. On the other hand, we identify, consciously or 
unconsciously, with religious traditions in which we happened to be born and/or stand and in the study of which we have spent a significant part of their lives.

The partial identification with liturgical rituals that we investigate may eventually lead to the need to help people overcome malfunctioning in spiritual and religious practices and the beliefs that interact with those practices. In liturgical studies, this is what Ronald Grimes has identified as 'ritual criticism', the evaluation and revision of rites. ${ }^{3}$ As examples of 'ritual criticism' one can think of analyses, evaluations, and revisions of liturgical ritual that initially worked to the exclusion of others: excluding women, people with disabilities, children, etc. One could also think of advice on the layout of the church space to match a shrinking or growing community or changes in liturgical insights. Or, in connection with the Lord's Supper, one could imagine a coherent ritual design of the offerings and the presentation of bread and wine that expresses the cohesion of the communion table and 'the table of the poor', thus of liturgy and diaconate. One could also engage a celebrating community in a discussion about the choice to use unleavened bread (as in the Paschal narrative of Exodus) or 'daily (healthy wholegrain) bread' in the sacramental celebration. At a more complex level, advice can be given on how to accommodate a wide variety of preferences regarding the worship service - evangelical or classical, organ or praise band - in a congregation. It becomes even more complicated when it comes to the relationship between worship and culture and, for example, the role that modern arts may play in worship. In this respect, as a specialist one collaborates with an ecclesial congregation and within the framework of that community. Normative advice in these cases is given on the basis of 'ritual criticism'. This is what Wisse calls therapeutic or irenic normativity (see below): on the basis of our knowledge and skills, and within the normative frameworks of a specific practice, developing suggestions for improvements. We often work together with the liturgical-ritual participants.

Regarding the religious traditions in which we happened to be born and/or stand we (Barnard and Klomp) note that we are generally reluctant to criticize or judge the liturgical-ritual practices that we study. Our research has led us to several 'foreign lands' and has taught us to behave as a guest in those lands. We have learned to suspend our normative judgment and to respect the lived religion of 'the other', even when our normative positions differ from our stances as researchers. We are particularly attentive to this in our work on the liturgical practices of (descendants of) people previously colonized by Western powers and in the context of a secularized society. However, we do take a more critical position within our own denomination.

On the other hand, we identify, consciously or unconsciously, with religious traditions in which we happened to be born and/or stand and in the study of which we have spent a significant part of our lives. Here we have a more critical attitude. Wisse speaks of elenctic normativity, the idea that the liturgical practice we (still Barnard and Klomp) criticize has the danger of losing the sacred (as we discuss below). With Roy Rappaport we can speak here of the 'True Words' that are spoken by religion. 
We should not misunderstand Rappaport, however; he does not advocate the use of these kinds of words, but rather sees them as a description of the claim and performativity of religious statements. When we speak of 'True Words' here, we do so in the awareness of their intended or unintended claims and performative power. Nevertheless, we are also conscious that they are positioned just as much as the evaluations and adaptions that are key in the irenic or 'ritual criticism' normativity. 'True Words' therefore remains in inverted commas. 'True Words' set benchmarks in the endless field of meaning of liturgical ritual or in a specific liturgical discourse. Rappaport thinks that it is specific to religion "to establish certain benchmarks - 'The True Word' - within the endless interpretative network of these languages [of the rites] on which other 'truths' are based". ${ }^{4}$ As Barnard and Klomp understand it, in the case of liturgical studies 'The True Word' is the insertion of a position held in a specific tradition that safeguards that tradition - or, more specifically, and to follow Wisse, the secret of the religious that asks to be protected from abuse. It intends to protect the sacred and to draw a line between the human and the divine.

The team of liturgical scholars at the Protestant Theological University, Amsterdam is mainly doing qualitative empirical research. As is usual in this type of research, an ontological positioning belongs to academic research, precisely because "the nature of the phenomena, or entities, or social 'reality', that I wish to investigate" involves asking "what you see as the very nature and essence of things in the social world". ${ }^{5}$ As the team includes researchers who are rooted in the classical reformed tradition, the Lutheran tradition, and a more ecumenical protestant tradition, they have different ontological views on the liturgy, including, specifically, the sacrament of the Eucharist. Our (Barnard and Klomp) sacramental thinking is strongly shaped by Lutheran theology as well as by the twentiethcentury liturgical movement, which also influenced the Reformed tradition in the Netherlands.

In short, we create a double normativity: on the one hand, we seek connection with the humanities and their dominant discourses as well as with practical theology and its current focus on demotic (ordinary colloquial) discourses. These disciplines include taking on internally critical positions, for example from what has come to be called 'ritual criticism': a ritual can be criticized from a culturalanthropological, a sociological, a psychological, or a practical-theological position without recourse to basic, often ecclesiastically established, theological positions. ${ }^{6}$ On the other hand, as ecclesiastically rooted theologians, we propose certain 'standards' that both arise from our theological roots and are meant to safeguard those roots; however, they want to bring these into conversation with other positions and standards. We do so, in other words, in the sense of our positionality.

4) Marcel Barnard, Johan Cilliers, and Cas Wepener, Worship in the Network Culture: Fields and Methods, Concepts and Metaphors, Liturgia Condenda 30 (Leuven: Peeters, 2014), 127. See also Roy Rappaport, Ritual and Religion in the Making of Humanity, Cambridge Studies in Social and Cultural Anthropology 110 (Cambridge: Cambridge University Press, 1999) 21f.

5) Jennifer Mason, Qualitative Researching (London: Sage Publications, 2002), 14.

6) Grimes, Ritual Criticism. 


\section{Dogmatics: irenic or therapeutic and elenctic normativity}

In a similar way, as in the development of liturgical scholars' approach to normativity, the search for a new form of conscious theological normativity happens in dogmatics or systematic theology more broadly. Since the Enlightenment, the infallibility of Scripture and tradition gradually fell apart, and in mainstream systematic theology the fragmentary character of Scripture and tradition, including all sorts of tensions and contradictions, is widely accepted. The question then is, however, whether systematic theology can still play a normative role and, if so, how. A whole range of options has been developed in this regard. Some of these options, such as Schleiermacher's theology, strive for grounding in human subjectivity. ${ }^{7}$ Others rely on Trinitarian metaphysics. ${ }^{8}$ Some borrow more consciously from the postmodern condition. Anglo-Saxon philosophical theology, for example, was very well aware of the relative nature of normative statements. Normative reflection could be seen as analyzing a certain standpoint and aiming at a point of view that is coherent, consonant with tradition, and relevant to the current situation. ${ }^{9}$ I myself (Wisse) arrived at the position in which the Lutheran distinction between Law and Gospel was decisive for practicing dogmatics today.

I have proposed to distinguish between two different types of normativity. ${ }^{10}$ These types are comparable to the two types of normativity in liturgical studies. I characterize the two types as irenic and elenctic. Irenic normativity brings otherwise unnoticed texts, beliefs, and practices to the attention of the faith communities it is engaged with. Such irenic forms of normativity seek to facilitate the life of the community and enhance their ability to handle the challenges it faces. Elenctic normativity is more critical. It issues a warning to the community, because those engaged with the community risk losing what is sacred to them.

Perhaps unnecessarily, we should point out that these 'norms' are not carved in stone and that, like Rappaport's 'True Words', they must always be placed in inverted commas. The Bible, the confessional writings adopted as normative by the Church, and the broader theological traditions are always read selectively. Also, what is traditionally accentuated or disappears into the background is a selective choice. Speaking normatively may therefore also involve recalling certain forgotten elements from the traditions to counterbalance overly dominant elements. In this sense tradition is always 'invented tradition'. ${ }^{11}$ It is precisely the irenic or therapeutic (or ritual-critical) dimension of normative theological

7) E.g., Friedrich Schleiermacher, Der Christliche Glaube: nach den Grundsatzen der Evangelischen Kirche im Zusammenhange dargestellt (1830/31), ed. Rolf Schäfer (Berlin: Walter De Gruyter, 2008).

8) E.g., Wolfhart Pannenberg, Systematic Theology, 3 vols. (Grand Rapids, MI: Eerdmans, 1991).

9) Vincent Brümmer, The Model of Love: A Study in Philosophical Theology (Cambridge: Cambridge University Press, 1993), 19-29.

10) Maarten Wisse, "De integratie van theologie en religiewetenschap in Stefan Paas' Vreemdelingen en priesters: De Utrechtse theologische faculteit in de jaren ‘90," Soteria 35, no. 1 (2018): 19-31.

11) Eric Hobsbawm and Terence Ranger, eds., The invention of Tradition (Cambridge: Cambridge University Press 1983). 
speaking that can bring to life forgotten, nearly forgotten, or consciously repressed moments from tradition. This is a given with the Christian faith.

The distinction between irenic and elenctic normativity, as two ways in which theologians can engage with beliefs and practices in religious communities or secular society, still sounds rather neutral. I (Wisse), however, developed this distinction on the basis of a more directly theological distinction: namely, the Law-Gospel divergence. This distinction goes back to Luther and Melanchthon and borrows from Paul and the Augustinian tradition. It suggests that in any theological expression, it is important to distinguish between what God demands and what God promises. When we translate this distinction into the way in which theology reflects on the discourse and practices of faith, we could say that theology is about affirming and exploring the mystery of God's presence in Jesus Christ among us, while at the same time protecting this mystery against abuse. This abuse is to be found in humanity's attempts to master the mystery of God's presence and manipulate it to its own benefit. Any theological endeavor that aims to enrich and reinforce the perception and appreciation of the mystery of Christ on earth belongs to the Gospel side of theology, the therapeutic or irenic side. Any attempt, by contrast, to critically protect the mysterious character of that presence belongs to the Law-side of theology, the elenctic side.

It is important to note that this view of normative reflection in theology does not lead to definite answers to every theological question. Rather, the interplay between Law and Gospel opens up a space in which the pros and cons of certain beliefs and practices can be compared. Comparing beliefs and practices is a communal and highly contextual endeavor, in which many historical and sociological aspects of a belief or practice can and should be taken into account. This is how historical, systematic, and practical theology mutually reinforce (and are mutually dependent on) one another.

The duality of Law and Gospel is already present in Scripture and the tradition of Christianity. Therefore, in the theological appropriation of Scripture and the tradition, the interplay between the irenic and the elenctic moment of theological reflection is already at work. Moreover, it is not only present in Scripture and tradition, but even in the human condition, as Rudolf Otto's notions of the tremendum ac fascinans show. ${ }^{12}$ It is insufficient, therefore, merely to borrow some part of Scripture or tradition, claim it is true, and apply it to some concrete issue of belief or practice so as to remain true to divine revelation. Alongside that part of Scripture or tradition, there are other parts that need to be taken into account. Nor is normative theological reflection a matter of proclaiming Christian truths in a secular society. Christian theology does not confront a secular society with a divine revelation that comes from without and that it must obey or reject. It rather continues a conversation about the mystery of life - demand and promise, task and gift, commission and dedication, fear and joy, dead and life, tremendum ac fascinans - that is already part of the human condition.

12) Rudolf Otto, Das Heilige. Über das Irrationale in der Idee des Göttlichen und sein Verhältnis zum Rationalen (Munich, 1917). 


\section{Integrating the two normative frameworks and revisiting the case}

In this section, we (Barnard, Klomp, and Wisse) aim to bring the two discourses as introduced above into conversation with each other and apply them to the case that brought us into these considerations about normativity in liturgical studies. We believe that the discourse of liturgical studies and systematic theology converge and can even be combined to form a common normative framework. In order to show this, we discuss how ritual criticism operates in the same mode as what Wisse calls irenic or therapeutic normativity and that speaking 'The True Words' can be compared to Wisse's elenctic normativity. This is significant in itself, because among theologians it is sometimes suggested that systematic theology's natural normative modus is that of speaking the true Word based on Scripture and tradition, whereas liturgical studies works to describe and 'anthropologically' criticize certain practices. We disagree, because this suggestion does not align with the way in which both liturgical studies and systematic theology actually work.

Above, we spoke about the 'interplay' and 'duality' of Law and Gospel. This word usage already suggests that the Law-Gospel distinction is not an absolute distinction. In the theological tradition, this is most visible in Luther's discussion of the Decalogue in the Large Catechism. There, he argues that fulfilling the first commandment is only possible through faith in Christ. ${ }^{13}$ From his perspective, the Law cannot exist without the Gospel. Although he is less explicit about it, the opposite also holds true: the Gospel cannot exist without the Law. The Law draws us to Christ, and as such it makes the Gospel shine more clearly than it would without the Law. Law and Gospel are fundamentally distinct and yet mutually dependent on each other. The same could be said for what we called irenic or therapeutic and elenctic normativity in theology.

Ritual criticism as practiced in liturgical studies aligns with irenic normativity, because ritual criticism is always about contextualizing and never about offering definitive answers. Whether, to what extent, or in what way a ritual 'works' is always dependent on the situation, and ritual criticism is always developed with the cooperation of the participants in the ritual in order to get them to view their rituals from a new perspective. The problems identified by dogmatic and liturgical scholars emerge from the ambiguities that are present in the beliefs and practices of the participants themselves. For example, the Lord's Supper may, in its design, have become too much of an inward-looking ritual that only refers to the community gathered around the table. The poor are thus left out of the picture or, to refer to the Lazarus of the Gospel, outside the gate. An irenic criticism of this design immediately evokes, elenctically, the commandment to care for the poor. Likewise, if we point out that at-home preparation of bread and wine in front of a screen pushes the reception of the gifts into the background, this is primarily an irenic, internal ritual criticism that suggests an ambivalence. However, this

13) Martin Luther, "Large Catechism," in Robert Kolb and Timothy J. Wengert, The Book of Concord

(Minneapolis: Fortress Press, 2000), 386. 
irenic criticism immediately evokes, elenctically, the question concerning the theological claim that it is Christ himself who is the gift of the Eucharist. This criticism does not deny that a ritual performed in this way also has meaning and evokes religious experiences. And here the conversation about the incarnational mystery of the Holy Communion starts, a point to which we will return below.

Something similar has happened in recent systematic-theological publications, which seldom judge the orthodoxy of someone's theological opinion in the light of Scripture and tradition. Rather, they present several authors' views, test their internal consistency, and provide a pro and con analysis. This analysis compares authors' opinions with elements from Scripture and tradition and notes the extent to which those opinions do justice to those elements from Scripture and tradition. Subsequently, a constructive attempt is made to enhance the thinking of the authors at hand by bringing other strands of tradition to the table. ${ }^{14}$ Nowhere in this procedure is there an absolute claim to truth. This absolute claim to truth might play a role in conservative dogmatics in the sense that it is believed that the more we make sure that everything we say is in line with Scripture and tradition, the closer we get to God's revelation. Among most mainstream systematic theologians, however, there is an awareness that Scripture and tradition do not form a coherent whole, and thus one will have to choose between different views in Scripture and tradition to form an opinion that can speak to the problems of today.

\section{Revisiting the discussion about an online Communion during a pandemic}

The coronavirus crisis and the debates about worship, especially a Holy Communion online, have challenged us to reflect on the normative positions we may or may not operationalize as academic theologians. Based on the journeys we have each followed in church and theology, we found two types of normativity that we have in common.

Looking back in terms of the distinction between irenic and elenctic normativity, the more theological distinction between Law and Gospel was already in play when Wisse published his advice. He was concerned as much about the risk that the mystery of faith would be made subject to human mastery as he was about the risk that they would be overly protective of the mystery and thereby do away with the incarnational mystery that the sacrament presents to us.

Wisse then sketched another option, which introduced spiritual communion as a way to deal with the problem. Comparing the medieval and pietistic Reformed tradition of spiritual communion to the present-day problem of celebrating the sacrament in an online service, he proposed that the minister celebrate together with the few who attended the service in the church, and those who watched

\footnotetext{
14) Cf. from the Dutch traditionally Reformed context: Arnold Huijgen, Divine Accommodation in John Calvin's Theology: Analysis and Assessment (Göttingen: Vandenhoeck \& Ruprecht, 2011). For an example from the Roman-Catholic tradition, cf. Gavin D'Costa, “On Being a Catholic Theologian," Theology 115, no. 1 (2012): 3-13. The approach described here is closely related to what has been recently termed 'theology of retrieval'; cf. Darren Sarisky, ed., Theologies of Retrieval: An Exploration and Appraisal (Edinburgh: T\&T Clark, 2017).
} 
the service online would only participate in the celebration spiritually. ${ }^{15}$ This step was a typical example of a therapeutic strategy. By adducing an old, often forgotten, or even disliked tradition and promoting it, Wisse aimed to provide a middle ground for those who did not want to prepare the signs of the sacrament at home, but also did not want to abstain from celebrating the Lord's Supper altogether. Here again, Wisse's concern was to provide a possibility of celebrating the sacrament in order to prevent a backlash to the reformed tendency to downplay the significance of the sacraments.

As a final step, Wisse suggested that it was possible to prepare the signs of bread and wine at home and celebrate together with the minister in the church by drawing an analogy between this practice and the already existing tradition of bringing the Eucharistic elements to the sick and homebound. This final step, which the board of the Synod of the PKN then recommended to congregations, was presented by Wisse as the most far-reaching; not only the 'benefits' but also the 'risks' were noted, such as the consequences for ecumenical relations.

Looking back, Wisse concludes that he took a rather therapeutic or irenic approach in his proposal to the board of the Synod. The fact that he did so was motivated by a strong awareness of the contextual character of the advice. The PCN is a church in which the Lord's Supper is celebrated and experienced in many different ways, and Wisse hesitated to formulate 'binding' advice to all those different congregations. Therefore, he sketched different trajectories that could align with different congregational practices.

Barnard and Klomp were both praised and criticized for their advice to postpone sacramental celebrations until the congregation can meet again physically in the church building. ${ }^{16}$ They suggested that people should refrain from digital forms of celebration, either as 'liturgy online' (that is, the digital distribution - whether recorded or streamed - of an analogous celebration in the church building) or as a 'mixed form' (where people prepare and eat bread and drink wine at home when the moment of the communion in the rite arrives). Looking back, we have to conclude that here irenic - or, rather, ritual-critical - as well as elenctic normativity played a role, though Barnard and Klomp were unable to make them explicit at that time, especially given the limitations of an opinion piece in a newspaper. They recognize that they crossed from one type of normativity to the other without much reflection. Their ritual-critical argument in the article was based on the emphasis on the physical aspect of the rite in both liturgical and ritual studies. ${ }^{17}$ In this respect, liturgical and ritual studies follows developments in, for example, the field of 'material religion' in religious studies or children's theology and feminist theology, as well as in postcolonial discourse and developments in wider society (emphasis on the

\footnotetext{
15) Compare the article of Cornet in this volume.

16) Barnard and Klomp, "Het avondmaal overslaan uit lijfsbehoud."

17) To give some examples of each: T.W. Jennings Jr., “On ritual knowledge," in R.L. Grimes, ed., Readings in Ritual Studies (Upper Saddle River, NJ: Prentice Hall, 1985), 324-34; D. Brown, God \& Grace of Body: Sacrament in Ordinary (Oxford: Oxford University Press, 2007); Barnard, Cilliers, and Wepener, Worship in the Network
} Culture, 207-43. 
role of the body in sports, fitness, wellness, fashion, food, etc.). In the elenctic-theological sense, their argument, firstly, referred to the physical and embodied concreteness of salvation in Christ and, as a consequence, to the incarnation. Secondly, it harkened back to the belief that ultimately the Lord himself is acting in the sacrament and that he is bodily present 'in, with, and under' bread and wine. Because this elenctic normativity in particular gave Barnard and Klomp the courage to give fairly strong advice, we will discuss this in more detail.

Firstly, they have the conviction, as they have expressed earlier, that the dining room table is, as it were, an extension of the altar or the communion table. This conviction is rooted in the diaconal aspect of the Lord's Supper: the Holy Communion is connected to the food crisis that the world is currently experiencing and the associated problems of hunger, poverty, and refugees. ${ }^{18}$ For that reason, they believe that a spiritualization of salvation - and, especially, of the sacrament - pushes the concrete nature of salvation as revealed in the Word becoming human, the incarnation, too much into the background. To frame it in an appropriate 'True Word': a person does not live by faith alone, and ultimately a screen does not feed mouths. Or, even more sharply: here the rite hinders the concreteness in which God meets the congregation.

Secondly, when we break bread and pour wine in obedience to the Lord's word 'do this in remembrance of Me' and when we say over the bread 'this is my body', Barnard and Klomp are well aware that this sentence refers to the non-present physical body of Christ. Nevertheless, they believe that the absent body of the crucified and risen Lord is present 'in, with, and under' bread and wine, as the Lord has promised. "But it is beyond our capabilities to make this absent/present body into 'a present-entity."'19 In other words, we receive that body, God gives Himself, and the appropriate rite is the congregation's reception of bread and wine, not the preparation of it themselves. In Barnard's and Klomp's opinion, when people prepare their own sacramental 'gifts', the boundary between the domain of God and man is crossed in the liturgical-ritual play. In the sacrament, God gives himself as one who serves, and so self-service is inappropriate. As a consequence, they thought that they were allowed to express a 'True Word' that was evoked in their mind by this practice. They wanted to warn against the threat that the mystery of God's presence in the sacraments be made subject to human mastery. Thinking about it afterwards, they would have done well to put this into perspective: "here," they might have said, "we see our rootedness in Protestant - Reformed as well as Lutheran - theology, in addition to our involvement with the twentieth-century liturgical and ecumenical movements that have deeply influenced reflections on the sacrament."

18) Cf. Mirella Klomp and Marcel Barnard, "The Global Food Crisis," in Martin Hoondert, Paul Post, Mirella Klomp and Marcel Barnard, eds., Handbook of Disaster Ritual (Leuven: Peeters, forthcoming).

19) Barnard, Cilliers, and Wepener, Worship in the Network Culture, 242. The quote is Heidegger as quoted in Louis-Marie Chauvet, Symbol and Sacrament: A Sacramental Reinterpretation of Christian Existence (Collegeville: The Liturgical Press, 1995), 58. 


\section{Conclusion and discussion}

In this article we reflected on normative arguments in a liturgical-studies or, more broadly, a theological discourse. We distinguished between ritual criticism and 'True Words', irenic and elenctic normativity, without being able to separate the two. Ultimately, an absolute norm within an academic discourse, or within a discourse that takes the findings of contemporary theological and religious studies into account, appears to be impossible. However, the distinction between Law and Gospel and the corresponding distinction between irenic and elenctic normativity opens up a space for weighing the pros and cons of a specific position. Moreover, it facilitates a conversation about the mystery of life and the mystery of the sacraments - the mystery of life, as demand and promise, as task and gift, as commission and dedication, as fear and joy, death and life, tremendum et fascinans.

Marcel Barnard is professor of Practical Theology/ Liturgical Studies at the Protestant Theological University (Amsterdam, the Netherlands) and at Stellenbosch University (South Africa). Email: mbarnard@pthu.nl

Mirella Klomp is assistant professor of Practical Theology/ Liturgical Studies at the Protestant Theological University (Amsterdam, the Netherlands) and Privatdozentin at the University of Bern (Switzerland).

Email: m.c.m.klomp@pthu.nl

Maarten Wisse is professor of Dogmatics at the Protestant Theological University (Amsterdam, the Netherlands) and extraordinary professor at the University of Tübingen (Germany).

Email: maarten.wisse@pthu.nl 